\title{
Current and Prospective Strategies on Detecting and Managing Colletotrichumfalcatum Causing Red Rot of Sugarcane
}

\author{
Md Imam Hossain ${ }^{1}$, Khairulmazmi Ahmad ${ }^{1,2, *}$, Yasmeen Siddiqui ${ }^{2, *}$, Norsazilawati Saad ${ }^{1}$, \\ Ziaur Rahman ${ }^{1}$, Ahmed Osumanu Haruna ${ }^{3,4}$ and Siti Khairunniza Bejo ${ }^{5}$ \\ 1 Department of Plant Protection, Faculty of Agriculture, Universiti Putra Malaysia, Serdang 43400, Selangor, \\ Malaysia; imam4all@gmail.com (M.I.H.); norsazilawati@upm.edu.my (N.S.); ziapath@gmail.com (Z.R.) \\ 2 Laboratory of Plantation Science and Technology, Institute of Plantation Studies, Universiti Putra Malaysia, \\ Serdang 43400, Selangor, Malaysia \\ 3 Department of Crop Science, Faculty of Agriculture and Food Sciences Bintulu Campus Sarawak, \\ Universiti Putra Malaysia, Bintulu 97008, Sarawak, Malaysia; osumanu@upm.edu.my \\ 4 Institute of Ecosystem Science Borneo, Faculty of Agriculture and Food Sciences Bintulu Campus Sarawak, \\ Universiti Putra Malaysia, Bintulu 97008, Sarawak, Malaysia \\ 5 Department of Biological and Agricultural Engineering, Faculty of Engineering, Universiti Putra Malaysia, \\ Serdang 43400, Selangor, Malaysia; skbejo@upm.edu.my \\ * Correspondence: khairulmazmi@upm.edu.my (K.A.); yasmeen@upm.edu.my (Y.S.); \\ Tel.: +60-126312550 (K.A.); Tel.: +60-176671219 (Y.S.)
}

Received: 24 June 2020; Accepted: 14 August 2020; Published: 26 August 2020

check for updates

\begin{abstract}
Sugarcane is an important industrial crop because it is the major source of white sugar. It is also one of the crops for the alcohol and biofuel industries. Disease-causing organisms can significantly decrease the productivity of sugarcane plants and sugar quality. Among the disease-causing organisms, Colletotrichum falcatum Went causes the most significant economic loss $(5-50 \%)$ in the sugarcane production due to red rot disease. This loss results in only 31\% sugar recovery. It is reported that $C$. falcatum can kill sugarcane plants. Currently, there is no sustainable way of preventing red rot disease from spreading in sugarcane plantations. Many popular sugarcane varieties are no longer used in sugarcane cultivation because of their susceptibility to C. falcatum. The objectives of this manuscript were to: (i) summarize existing approaches for the early detection of red rot disease and controlling techniques of red rot disease in the field and laboratory and (ii) assess red rot disease control effectiveness so as to propose better methods for mitigating the spread C. falcatum. If our proposition is adopted or practiced, it could significantly contribute to the mitigation of C. falcatum infection in the sugarcane industry. This could enable achieving sustainable cultivation of sugarcanes to guarantee the sustainability of the sugar industry in the tropics and the subtropics.
\end{abstract}

Keywords: Colletotrichum falcatum; sugarcane; red rot disease; detection and management

\section{Introduction}

Sugarcane (Saccharum officinarum L.) is regarded as one of the essential cash crops because it improves the socio-economic livelihood of many sugarcane growers [1,2]. Although sugar is widely used in our daily lives, there is a growing interest in sugarcane as one of the potential economic crops for bio-energy (ethanol) production [3]. The worldwide occurrence of sugarcane is approximately 26.3 million hectares and the gross production is approximately 1.9 billion tons [4]. The major sugarcane producing countries are Brazil, India, Thailand, Pakistan, China, Mexico, United States of America and Australia [5]. In spite of the public concern about the excessive sugar consumption in the world, 
the daily consumption of sugar is on the increase trend especially in the developing countries where the per capita consumption is relatively low [6]. For example, the global sugar demand is projected to increase to $203 \mathrm{Mt}$ by 2028 and this will add $32 \mathrm{Mt}$ to the existing tonnage. Increasing the demand for sugar will be driven by Asian, Middle Eastern and North African countries [7]. In addition, the sugar industry is playing a key role in improving the socio-economic status of many people through resource mobilization, job and rural infrastructural development, especially in the sugarcane growing countries.

Currently, the small-scale sugarcane planters are facing many challenges including biotic and abiotic factors. These factors have been implicated in the decreasing sugarcane production. The abiotic factors include extreme heat, drought, typhoons, flooding, frost and poor soil fertility [8]. It is believed that, productivity of the sugarcane plants is reduced because of water stress. The life cycle of sugarcane plants is affected by approximately 240 sugarcane diseases [9]. Approximately 100 fungi, 10 bacteria, 50 nematodes, and 10 viruses have been identified as pathogens of sugarcane worldwide $[10,11]$. Out of the many biotic stresses of the sugarcane, the Colletotrichum falcatum Went causes significant reduction in the quality and yield of susceptible sugarcane cultivars [12]. The red rot occurs in 68 sugarcane producing countries [13]. This disease decreases sugarcane yield by $5-50 \%$. The loss results in only $31 \%$ sugar recovery [14]. Besides reducing yield attributes, the red rot reduces the sugarcane juice quality (as sucrose content, purity, Brix) and commercial cane sugar [2]. Red rot disease is the major disease due to the destructive effects of the disease as the main cause for the withdrawal of the many sugarcane varieties in the sugarcane cultivation worldwide [15]. The variation in the morphologic and pathologic characteristics of the genus of Colletotrichum are related to their geographical origins. However, because of many overlapping characteristics within the species' complex, identification using morphologic techniques is not enough. Moreover, managing red rot disease in the field is difficult as the genetic makeup of this fungus keeps changing [16]. Therefore, accurate and rapid identification of Colletotrichum is essential. To date, there is no effective management of red rot disease because of the frequent breakdown of resistant cultivar. To develop resistant cultivars, breeders need to know races of the red rot pathogen. There is dearth of information on early detection and control strategies for C. falcatum.

The objectives of this manuscript were to: (i) summarize the existing approaches for early detection of red rot disease and controlling techniques of red rot disease in the field and laboratory and (ii) assess red rot disease control effectiveness so as to propose better methods for mitigating the spread C. falcatum.

\section{Pathogen, Infection and Transmission}

Colletotrichum falcatum belongs to the Ascomycota phylum. This pathogen is a facultative parasite. It occurs in anamorphic and teleomorphic forms but the amorphic stage which infects standing canes is the most important stage. The distinctive morphological and cultural characteristics of C. falcatum include the development of acervuli with setae, presence or absence of teleomorph, pinkish appearance of colony, sporulation and growth rate [2,17]. These characteristics are well described by Sharma et al. [18]. Many fungal isolates are significantly different [13]. Diversity in virulence within pathotypes had revealed that a red rot pathogen undergoes adaptive changes in host cultivars.Viswanathan et al. [19] reported that isolates are virulent in susceptible varieties, but not in resistant and moderately susceptible varieties. Virulence frequencies of isolates range from $21.3-40 \%$ on mildly susceptible varieties compared with $62.9-97.9 \%$ on susceptible varieties. This suggests that C. falcatum isolates differ in their host infectivity. Thus, it is very important to identify the extent of pathogen diversity and the way infection occurs to develop effective disease control and planting management [20].

Many sources of inocula are involved in the transmission of the disease. The pathogen is primarily disseminated through soil and diseased setts, whereas secondary distribution is through irrigation water, rainfall splashing, midrib lesion dew brushing, wind dispersal and other field vectors [21]. The relative importance on how inoculum is spread depends on the time of the year and the conditions under which the cane is growing. The pathogen infects stalks through nodes leaf scar, growth ring, 
root primordial and buds. The pathogen enters the nodes of a sugarcane plant through the inner epidermis of the lower part of the leaf sheath of this plant. In an unfavorable condition, the fungus produces appressoria on rind and leaves. Late in the season, the infection restarts by the placement of healthy plants. The Life cycle of Colletotrichum falcatum Went in sugarcane plants is summarized in Figure 1. The existence of the spot on sugarcane plants is not an evidence of their stalks' susceptibility to red rot disease.

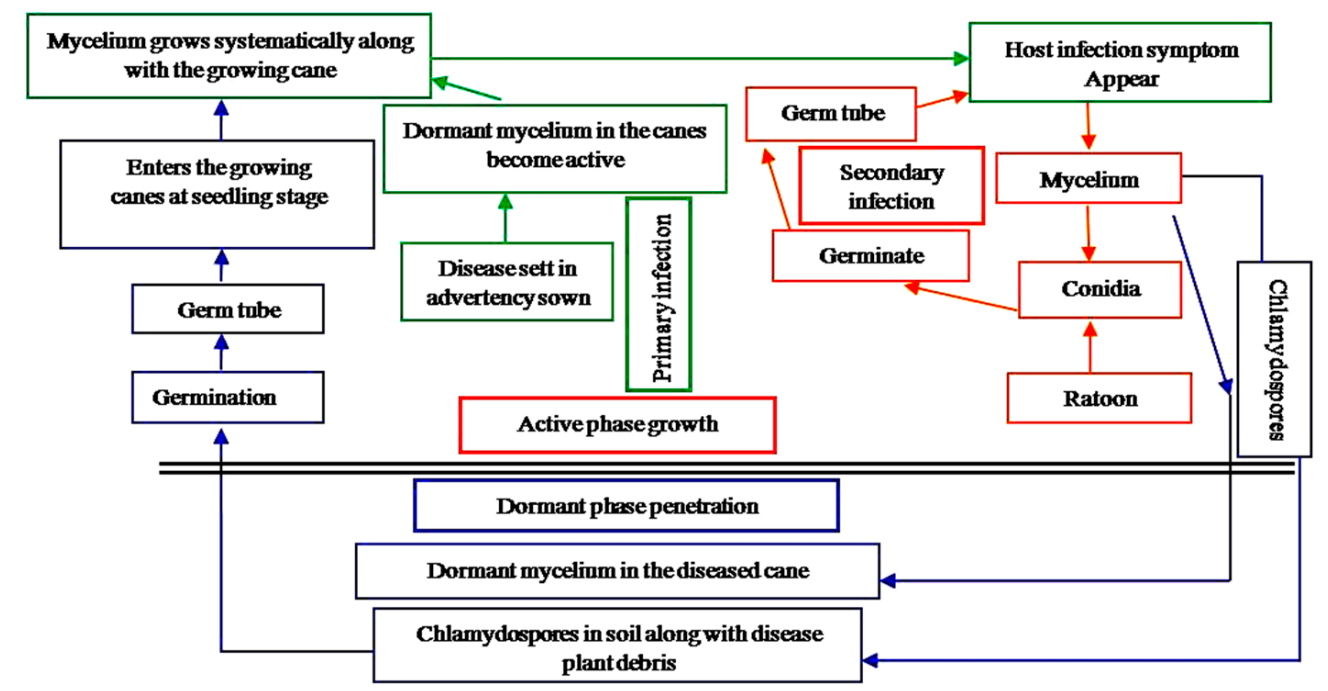

Figure 1. Life cycle of Colletotrichum falcatum Went in sugarcane plants. Green boxes indicate path of primary infection; orange boxes indicate secondary infection; blue boxes indicate dormant stage.

During soil borne transmission, latent fungal structures, namely appressoria, dense-walled hyphae chlamydospores, and setae play important roles in the dispersal of disease [22]. Colletotrichum falcatum thrives on unhealthy stalks or stubble fragments. Although C. falcatum is not a definite soil-inhabitant pathogen, there is enough evidence to suggest that fungal propagules are perpetuated by debris borne inocula [23]. The red rot appearance depends on type of the infection and environmental conditions [24]. Usually disease occurs at early growth stages and symptoms are often difficult observe [25]. The red rot disease is divided into four types, namely tiller, lamina, mid rib and stem red rot. The symptoms of the tiller red rot are generally identified as stunted plant growth with dry and straw colored leaves (Figure 2a).

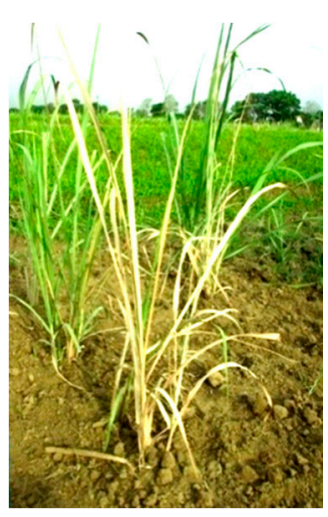

(a) Tiller red rot

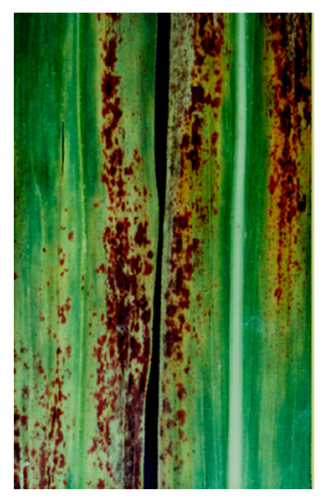

(b) Lamina red rot

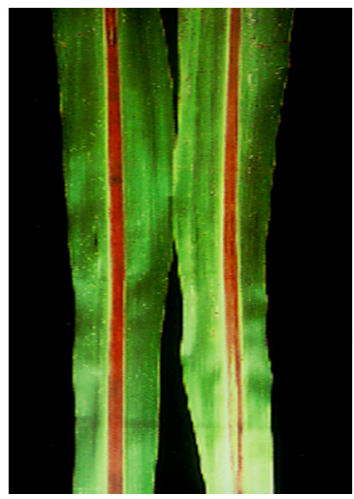

(c) Midrib red rot

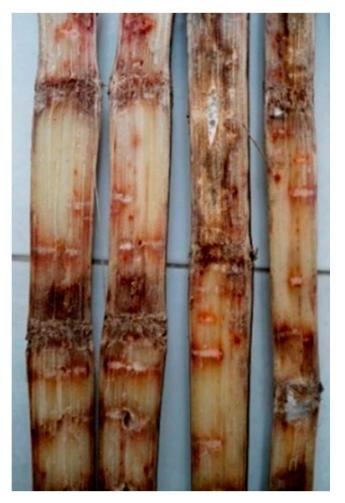

(d) Stem red rot

Figure 2. Typical disease symptoms of red rot on different plant parts and stages of sugarcane in the field. note: (a) tiller red rot observed at tillering stage; (b) lamina red rot, (c) mid rib red and (d) stem red rot observed at later stage of sugarcane in the field. 
The infection also causes alterations in the color of the lamina leading to straw color in the middle and dark reddish-brown on the edges as the black acervuli progresses (Figure $2 b$ ). Eventually, the infected leaves split and hang at the lesions, whereas, in the rib red rot, red color is observed through the whole mid rib (Figure 2c) [10]. Reddening of the internal tissues with alternating red and white patches (with an alcoholic scent) (Figure 2d) are the main indicators to suggest occurrence of the disease in the stalk at the later stages. Generally, the disease symptoms appear when leaves of the spindle (3rd and 4th leaves) show drying that wipe the top along the leaf margins. This discoloration persists from the tip to the base until all the crown leaves wane and red rot infected canes are separated from the nodes easily [26].

\section{Identification of Colletotrichum falcatum}

The most important requirement in any good disease management practice is the accurate identification of the pathogen. Characterization of $C$. falcatum isolates by cultural, pathologic and molecular methods are commonly used to confirm the presence and to study the genetic and phenotypic diversity within a population [26,27]. The different methods that have used to identify C. falcatum are subsequently discussed.

\subsection{Traditional Methods}

The traditional approaches that are used to detect and identify diseases include isolation and characterization pathogens using inoculation testing [26,28]. Colletotrichum species are described primarily based on morphologic features such as mycelia development, production of mycelia dry matter, mycelia color, texture, topography, shape and size of conidia [29]. The conidia of Colletotrichum species are easily seen using a compound microscope, but the accuracy of the conventional identification method and its reliability depend on depth of experience [30]. In addition, phenotypic detection is time-consuming and requires skilled or skillful personnel [31,32]. However, because of the many overlapping characteristics within the species complex, identification using morphologic techniques is not enough [33]. Pathogenicity and virulence tests are also another part of the conventional techniques for the identification of plant pathogens $[11,25]$. Generally, the pathogenicity test requires longer time to confirm the pathogen [34]. Moreover, the morphologic and pathologic identification techniques are time-consuming. In addition, these techniques are significantly affected by environmental factors $[35,36]$.

\subsection{Serologic Methods}

Serological methods are used to identify red rot fungus. A body of knowledge has been developed on the serological variability among C. falcatum isolates using for example, enzyme-linked immune sorbent assay (ELISA) technique [34]. The findings of Viswanathan et al. [34] suggest the possibility of using the serological technique to quantify the pathogen colonization and how they correlate with host resistance. Based on C. falcatum colonization in cane stalk, Viswanathan et al. [34] classified the host reaction to the pathogen as resistant, moderately resistant and susceptible. The authors concluded that the pathogen colonization was higher in nodal regions compared with the intermodal tissues. Hiremath and Naik [37] tried to detect $C$. falcatum in sugarcane tissue using multiple serological analyses such as ELISA, dot immune binding assay (DIBA) and western blotting. Viswanathan et al. [34] demonstrated that the ELISA technique could detect $C$. falcatum infection of sugarcane tissue in stalks using polyclonal antiserum raised against the pathogen. In addition, they found that the isolated polyclonal antibodies were specific to C. falcatum. Khalid et al. [38] isolated two protein molecules from the mycelium of C. falcatum race cf. 05 at $27 \mathrm{kDa}$ and $45 \mathrm{kDa}$ molecular weights-after which it was used to develop polyclonal antibodies. The antibodies produced were species specific and they had high affinity for C. falcatum (1:50,000 and 1:500 dilution). Another simple, fast and targeted assay for the laboratory analysis of sugarcane (C 671) red rot (at the early growth stage of sugarcane plants) using DIBA with dilution ratios of 1:1000 and 1:100 antigen and secondary antibody, respectively [37]. Although 
these techniques are promising, the disadvantage of the serologic tests is the possibilities of false positives. The false positives are caused by cross-reaction of antibodies with plant debris or unrelated organisms [38]. Using ELISA, Viswanathan et al. [34] showed that seed cane indexing is possible for red rot infection. This index identifies red rot resistance in a shorter time, and it can also be used to screen large populations. This technique is appropriate for rapid screening because it enables early detection of pathogen colonization before symptoms are evident. In addition, the technique enables pathogen assessment load of different nodal sites of sugarcane plants with plant growth promoting rhizobacteria [37]. However, the nonspecific reaction caused by certain cane tissues we must be fixed.

\subsection{Molecular Method}

Colletotrichum species are characterized using different molecular approaches. Unlike the traditional methods, molecular techniques not affected by environmental factors. The presumed existence of intermediate forms between species, morphologic plasticity and overlapping of the phenotype make the use of the traditional method less effective. These barriers hinder the use of classical criteria to identify these pathogens. As a result, the molecular biology technique encompasses alternative and supplementary approaches because they are important techniques for overcoming the difficulties in identifying up to species level [39]. For the good detection of Colletotrichum species, molecular phylogeny combined with morphologic and cultural traits, pathogenicity and physiological tests are recommended $[40,41]$. Molecular approaches such as sequence analysis of the internal transcribed spacer (ITS) region between large and small subunits of ribosomal DNA (rDNA) are commonly used to detect fungi such as Colletotrichum spp. [27]. Combination of multiple genes characterization, such as ITS, actin, glyceraldehydes-3 phosphate dehydrogenase (GPHD) and beta-tubulin could offer more accurate for identification of fungal taxa (Table 1) [42]. Inter simple sequence repeat (ISSR) markers have been effective multilocus markers for genetic diversity analysis, finger printing and mapping of genomes. This approach enables us to understand pathogen population dynamics $[43,44]$. The advantages of ISSR markers are semi-arbitrary markers, highly polymorphic, highly informative, low cost and only low quantities of template DNA are needed [45]. To successfully improved crop productivity, genetic characterization of pathogenic variants of crop pathogens is essential [46]. Molecular biology is a good tool for fungal taxonomists. The approach is reputed for enabling rapid identification of isolates and clarification of the relationships between fungal organisms [47].

Viswanathan et al. [48] documented that C. falcatum draft genome size is approximately $48.16 \mathrm{Mb}$. This genome has 12,270 genes with $90 \%$ and $84 \%$ identical genes for C. graminicola and C. sublineola, respectively. In addition, Viswanathan et al. [48] reported that $C$. falcatum genome has plant cell wall degrading enzymes (CWDE), transposable components, primary secondary metabolites, candidate secretory effectors (CSEPs), membrane carriers, signaling molecules, carbohydrate-active enzymes (CAZymes), matting proteins, sclerotic development proteins and a special member of the Colletotrichum family. This report improves our understanding on species that are close to C. falcatum.

Scindiya et al. [49] showed that RNA-mediated silencing of PKS1 gene in C. falcatum causes the red rot in sugarcanes. The authors believe that the gene homologs are responsible for $C$. falcatum virulence and its pathogenesis. Scindiya et al. [49] showed that two isolates-viz., Cf 671 and Cf92020 differed phylogenetically with multiple gene homologs differing in their virulence. Intra and interspecific variation as well as genomic sequenced origins between two C. falcatum isolates (Cf671 and Cf92020) have been identified. During interaction with the host-pathogens, expression of pathogenic gene homologs with both isolates occurs. Scindiya et al. [49] showed that molecular approaches can be used to differentiate between closely related species with few morphologic differences and stains or even distinct isolates within the species. 
Table 1. Colletotrichum falcatum nucleotide sequences available in public domain database.

\begin{tabular}{|c|c|c|c|c|}
\hline Accession Number & Sequence Length (bp) & Product & Source & Year of Release \\
\hline NR144793 & 539 & 5.8S rDNA & CBS 127,945 & 2018 \\
\hline MH868869 & 894 & large subunit ribosomal RNA gene & strain CBS 275.54 & 2020 \\
\hline KC790965 & $583 \mathrm{bp}$ & $5.8 \mathrm{~S}$ ribosomal RNA & strain LC0885 & 2014 \\
\hline KU220963 & $553 \mathrm{bp}$ & 5.8S ribosomal RNA & isolate RR03 & 2016 \\
\hline MK850182 & $584 \mathrm{bp}$ & $5.8 \mathrm{~S}$ rDNA & isolate I-2 & 2019 \\
\hline MN636356 & $582 \mathrm{bp}$ & $5.8 \mathrm{~S}$ rDNA & isolate I-39 & 2019 \\
\hline MK937676 & $492 \mathrm{bp}$ & 5.8S rDNA & strain 1802020746Q & 2019 \\
\hline NR144793 & $539 \mathrm{bp}$ & $5.8 \mathrm{~S}$ ribosomal RNA & strain CBS 127,945 & 2018 \\
\hline AF275524 & $556 \mathrm{bp}$ & small subunit ribosomal RNA gene & strain A97 (CBS 252.59) & 2000 \\
\hline JQ005772 & $539 \mathrm{bp}$ & ITS1, 5.8S rRNA gene & strain CBS 147,945 & 2013 \\
\hline КС790965 & $584 \mathrm{bp}$ & ITS1 $1.5 \mathrm{~S}$ complete rRNA, $18 \mathrm{~s}$ and $28 \mathrm{~s}$ rRNA partial sequence & strain LC0885 & 2014 \\
\hline MN636354 & $537 \mathrm{bp}$ & $5.8 \mathrm{~s}$ rRNA & strain I-42 & 2019 \\
\hline JQ005856 & $484 \mathrm{bp}$ & beta-tubulin (TUB2) gene, partial cds & strain CBS147945 & 2013 \\
\hline MK867418 & $750 \mathrm{bp}$ & beta-tubulin (TUB2) gene, partial cds & strain I-40 & 2019 \\
\hline AJ409290 & $545 \mathrm{bp}$ & beta-tubulin (TUB2) gene, partial cds & isolate 80 & 2016 \\
\hline HM171680 & $682 \mathrm{bp}$ & beta-tubulin (TUB2) gene, partial cds & isolate LC885 & 2011 \\
\hline MK867410 & $750 \mathrm{bp}$ & beta-tubulin (TUB2) gene, partial cds & isolate I-19 & 2019 \\
\hline MK867412 & $750 \mathrm{bp}$ & beta-tubulin (TUB2) gene, partial cds & isolate I-24 & 2019 \\
\hline MK867417 & $750 \mathrm{bp}$ & beta-tubulin (TUB2) gene, partial cds & isolate I-38 & 2019 \\
\hline MK867380 & $272 b p$ & actin (ACT) gene, partial cds & isolate I-5 & 2019 \\
\hline JQ005835 & $252 \mathrm{bp}$ & actin (ACT) gene, partial cds & strain CBS 147,945 & 2013 \\
\hline KP895580 & $253 \mathrm{bp}$ & actin $(\mathrm{ACT})$ gene, partial cds & isolate 238 & 2015 \\
\hline MK867393 & $271 \mathrm{bp}$ & actin (ACT) gene, partial cds & isolate I-27 & 2019 \\
\hline MK867379 & $271 \mathrm{bp}$ & actin $(\mathrm{ACT})$ gene, partial cds & isolate I-2 & 2019 \\
\hline FJ002020 & $152 \mathrm{bp}$ & glyceraldehyde 3-phosphate dehydrogenase gene, partial cds & isolate Cf64-8 & 2019 \\
\hline MK867433 & $150 \mathrm{bp}$ & glyceraldehyde-3-phosphate dehydrogenase gene, partial cds & isolate $\mathrm{I}-27$ & 2019 \\
\hline FJ001997 & $152 \mathrm{bp}$ & glyceraldehyde-3-phosphate dehydrogenase gene, partial cds & Cf419 & 2019 \\
\hline FJ002002 & $152 \mathrm{bp}$ & glyceraldehyde-3-phosphate dehydrogenase gene, partial cds & isolate $\mathrm{Cf} 86032 \mathrm{C}$ & 2019 \\
\hline JQ005793 & $280 \mathrm{bp}$ & Chitin synthase 1 (CHS1) gene, partial cds & strain CBS147945 & 2013 \\
\hline JQ005814 & $385 \mathrm{bp}$ & histone (HIS3) gene partial cds & strain CBS147945 & 2013 \\
\hline
\end{tabular}

Source: National Center for Biotechnology Information (NCBI). 
According to Nandakumar et al. [50], green fluorescent protein (GFP) can be used to explore the interactions between $C$. falcatum and sugarcane to establish pathogenesis, colonization and dissemination of this fungus in host tissues.

The authors demonstrated that the GFP transformed C. falcatum strain was firmly incorporated in the mitotic stability. Moreover, the C. falcatum transformants retained morphologic features and growth parameters because the wild type and virulence type were not altered relative to wild C. falcatum. The $C$. falcatum pathotypes tagged with GFP specifically showed differences in C. falcatum colonization through cooperative and incompatible sugarcane encounters. However, these molecular methods are expensive and need specific primers to amplify DNA for identification of pathogens.

\subsection{Image Processing Method}

Padhy et al. [51] reported that image processing techniques are innovations in agriculture and one of such innovations is automatic disease detection. Computer vision-based image processing techniques and detection algorithms had been used detect midrib red rot, leaf scald and mosaic diseases in sugarcane [52]. The steps involved in this disease detection method are image acquisition, image preprocessing, image segmentation and feature extraction and classification. The image processing method is not commonly used in the field because the length and width of the sugarcane leaf blade vary upto 60 inches and three inches, respectively. Proportional adjustments are required to cover the entire leaf region. Disproportional changes can reduce image resolution, resulting in poor segmentation of the diseased section of leaves. To increase precision, it is essential that leaves are cut into pieces. Another important factor in image acquisition is that the rate of evaporation of sugarcane is 150 to 200 times greater than in other plants. As a result, the sugarcane leaf wrinkles after it is removed from the stem. Therefore, rapid capturing of the images is recommended. This method gives rapid results. It must be stressed that because the image processing method is a new innovation more experimental results are required to validate the method.

\subsubsection{Fluorescence Imaging}

Noninvasive strategies to photograph multispectral fluorescence patterns or leaf temperatures across contaminated plants have significantly improved our knowledge on plant responses to biotic stress (Figure 3).With this technique, chlorophyll fluorescence is measured as an incident light factor on plant leaves, and variations of the fluorescence parameters are used to examine the response of pathogenic pathogens to changes in photosynthetic system and pathways of photosynthetic proton transport [52-54]. Temporal and spatial differences in chlorophyll fluorescence had been used to successfully detect causative pathogens with powdery mildew and leaf rust in wheat leaves [52]. Although this technology can be used to detect diseases and photosynthetic anomalies in sugarcane leaves, the practical use of the technique in the field is limited [55].

\subsubsection{Thermography in Disease Detection}

Thermography provides information on the variations in plant leaves' surface temperature and plant canopies.Thermographic cameras can track emitted infrared radiation as well as analyzing color variance. Earlier studies had suggested that phytopathogens can inhibit lack of water in stomata-regulated plants [56,57]. Thermographic imaging can monitor the resulting infection, and the volume of water culminated can be calculated without specific temperature considerations [57]. Several research scientific groups have related plant pathogen infection to temperature changes [53,57-59]. For good identification of plant diseases, thermographic evaluation of plant diseases can also be scaled up (Figure 4) [60]. For example, thermographic image of healthy oil palm tree is compared to palm infected with basal stem rot disease (BSR). The images captured at the same scale can suggest that temperature of the leaves of BSR-infected trees is higher than the leaves of healthy trees. Thermography is also a good means of measuring soil borne pathogen infection heterogeneity [61]. Nevertheless, because of their high susceptibility to changes in environmental 
conditions, the practical application of thermography in disease control is limited. Thermographic identification is usually disease-specific and because of this limitation it is not capable of differentiating diseases with identical thermographic patterns.

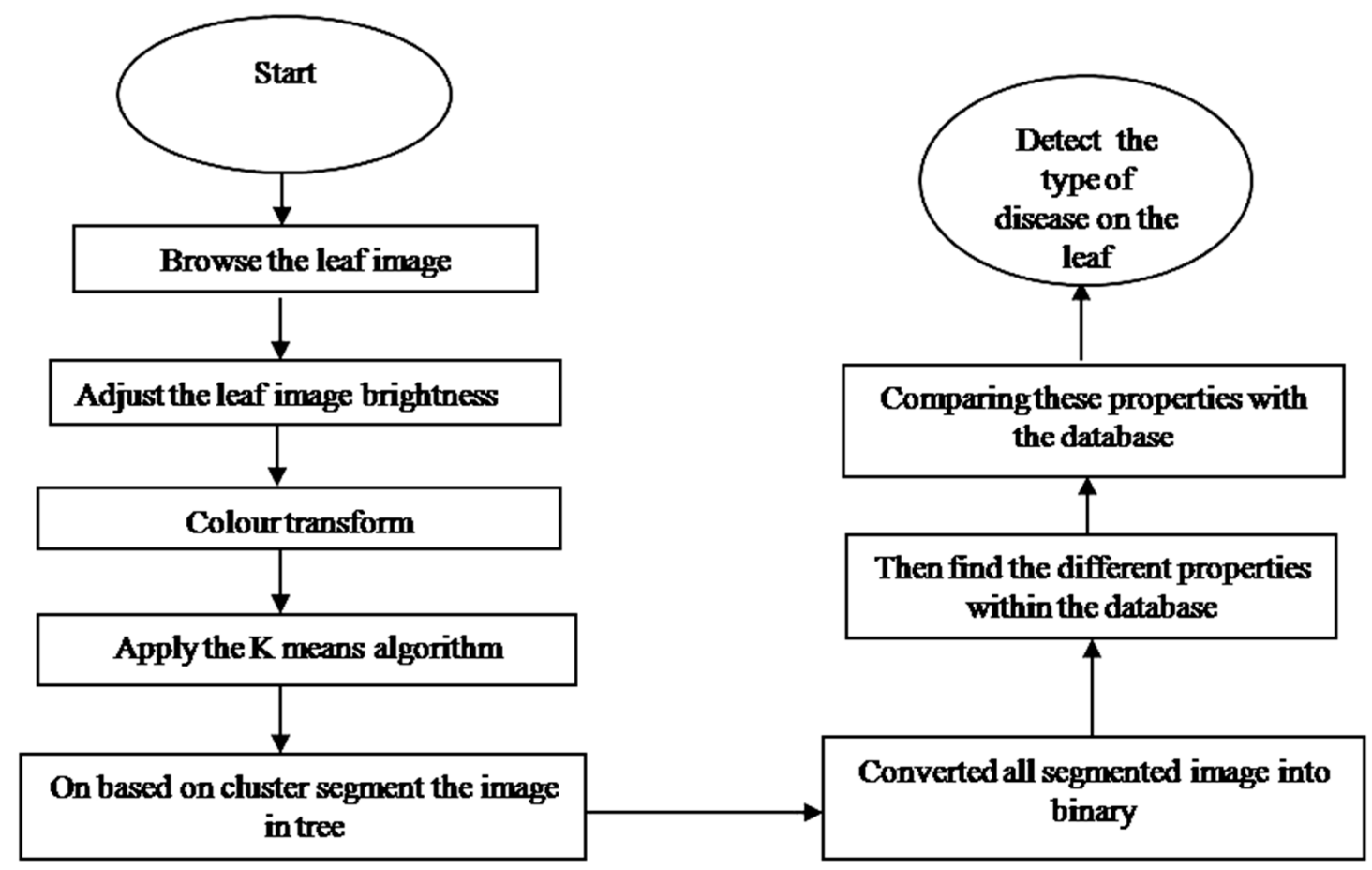

Figure 3. Flowchart of the leaf disease detection algorithm adapted from Khan et al. [52].

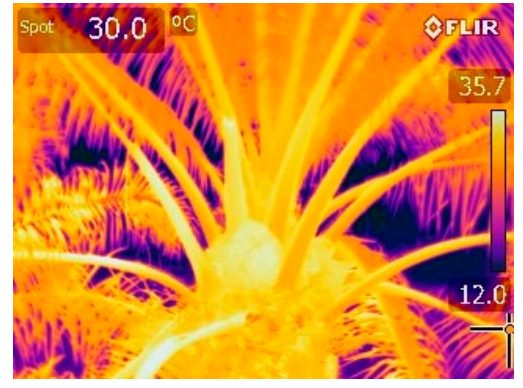

Original image

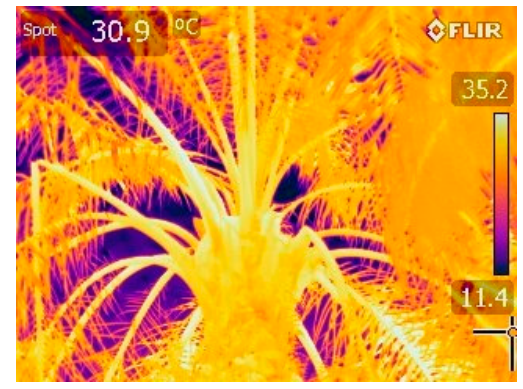

Original image

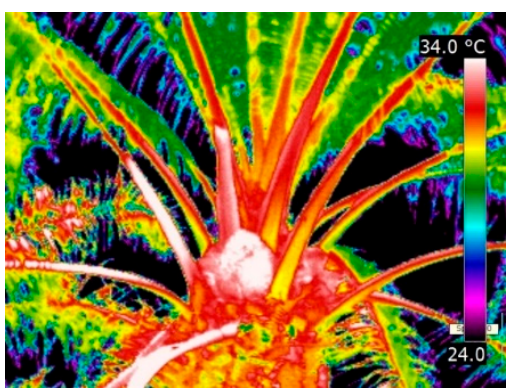

Scaled image

(a)

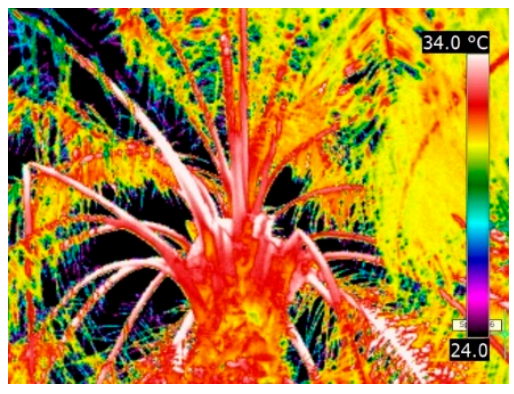

Scaled image

(b)

Figure 4. Thermal images of (a) healthy palm (b) basal stem rot (BSR)-infected palm. When the images used the same scaled, the temperature of the leaves taken from BSR-infected palm was higher than the healthy palm. 


\subsubsection{Hyperspectral Imagery}

Hyperspectral imagery can be used to gather valuable information on the health of plants over a wide range of wavelengths ( 350 to $2500 \mathrm{~nm}$ ).With hyperspectral imagery, valuable information on plant canopies such as chlorophyll pigment status, plant cell structure condition and plant structural water content can be obtained. In production agriculture, hyperspectral imagery is widely used for the detection of crop diseases. This technology is versatile and offers rapid interpretation of image data. For sugarcane diseases, Apan et al. [62] analyzed multiple narrowband indices from EO-1 Hyperion imagery (Figure 5). Forty spectral foliage indices were produced with emphasis on leaf pigment-based lines, internal leaf composition and water content of leaf. Discriminatory function analysis was used to pick an optimal range of indices dependent on their similarities to the discriminatory method. The outcome showed that Hyperion imagery can be used to identify orange rust disease in sugarcane crops. The findings suggested that the spectral reflections (signatures) in the areas with sugarcane orange rust disease were significantly different. Although sugarcane plants are vulnerable to multiple diseases and pests, only Apan et al. [62] conducted a research to identify and delineate infested cane areas using hyperspectral remote sensing. Research on orange rust disease diagnosis showed positive outcomes using hyperspectral remote sensing. Nevertheless, further research is required to identify the pests and diseases that are caused by other phytopathogens. Although the hyperspectral technology has worked well in association with different methods of band analysis and pattern recognition algorithms [63], more research projects are needed to improve information on ease of use, large scale coverage, plant variability and the economic viability for using this technology.

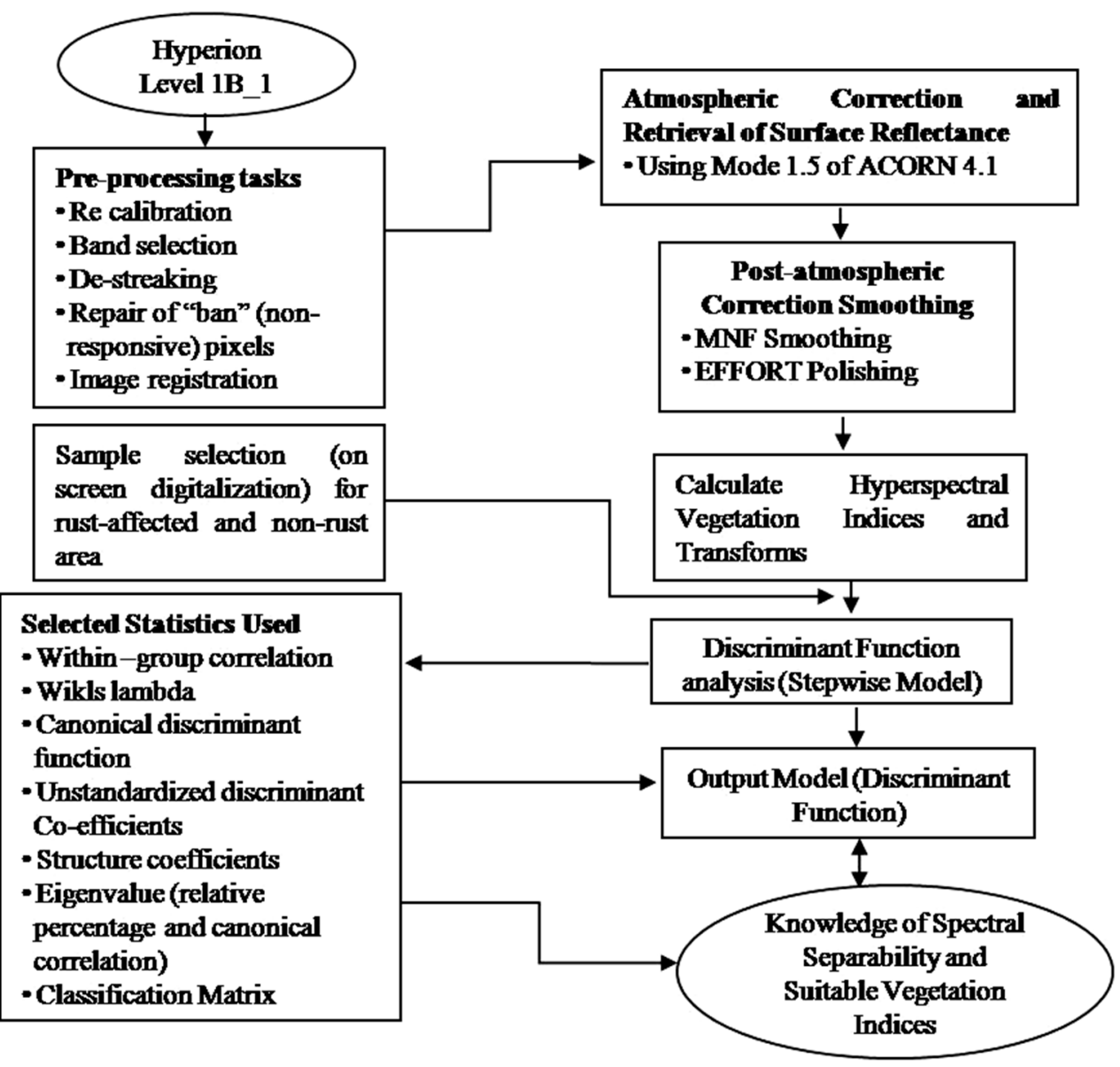

Figure 5. Main steps in the hyperion image processing for spectral differentiation of orange rust sugarcane adapted from Apan \& Held et al. [64]. 


\subsection{DNA/RNA-Based Affinity Biosensor}

Anew affinity biosensor had been developed using nucleic acid fragments as pathogen identification components. The DNA-based biosensor enables early identification of diseases before occurrence of visible symptoms. This is based on probability identification at molecular level. The specific DNA sequences had been widely used to classify genetically engineered organisms, viruses and fungi. Depending on the precise nucleic acid hybridization on the sensor and DNA analytes sequence of immobilized DNA probe DNA-based biosensor, it is possible to identify genetic and infectious diseases rapidly, reliably and accurately. The most commonly used DNA assay is the single stranded DNA (ssDNA) on electrodes with electro active markers to test hybridization between the DNA source and the supplementary DNA analysis [65]. The identification of DNA analytes is achieved based on the differences in physio-chemical characteristics such as mass, temperature, optical and electrical characteristics resulting from the two-stranded DNA hybridization (dsDNA) that occurs during the analysis. Although the use of DNA-based biosensors for the detection of plant diseases is promising, it requires small amount of nucleic acid and PCR is often required before continuing to the downstream analysis [66]. The drawbacks of biosensors based on DNA include a single DNA detector synthesis criterion, target DNA amplification, high cost (DNA-based molecular beacons) and insufficiency for real-time detection.

\section{Management of Red Rot Disease}

Red rot disease management is conventionally based on cultural practices, use of resistant varieties, disease free planting materials, physical, biologic and chemical control, among others. These methods are intended to restrict incidence of red rot after replanting to increase the productivity of sugarcane plants. However, the management strategies for minimizing red rot incidence had not yielded acceptable results [23]. To date, no single method is able to mitigate the disease incidence. Integrated disease management (IDM) is one of the excellent practices for disease control approaches. Integrated disease management practices decrease red rot occurrence, increase growth parameters and increase sugarcane performance attributes compared to non-IDM practices. Integrated disease management involves all the methods of disease control. The subsequent discussion focuses on this aspect.

\subsection{Agronomic and Cultural Practices}

Opting for the good agricultural practices and integrating cultural and biologic control methods as a preventive measure should be of utmost priority. The use of healthy planting materials, certified seeds, field sanitation, crop rotation and proper drainage facility could significantly minimize red rot disease. These cultural practices have been suggested not only to reduce the inoculum from the field, but to also reduce crop losses. Mono cultivation of the same crop with the same cultivar increases the inoculum level resulting in the development of the disease. The crop must be rotated after two to three years/cycles in the heavily infested field and the ratooning should be discouraged [18]. Considering that red rot disease is seed/sett-borne, disease-free nursery should be adhered to [24]. Authorized enforcement of nursery programs is very important. Disease and pest free seeds/setts and mixtures with other varieties must be guaranteed. The most useful method for control of the pathogen is the use of disease-free setts.

Jain [67] reported that the geographical origins of pathogen isolates had not been related to molecular and pathologic heterogeneity. This suggests that the most effective ways of avoiding this destructive disease is through the use of disease-free planting inputs in commercial cultivation. Adopting field sanitation practices such as removing and burying of crop debris, withered leaves, stubble, among others before planting is essential [68].Sugarcane fields should be well leveled, and hygienic farming should be adhered to. Regular field inspection and roughing of diseased plants could minimize the occurrence of red rot disease [10]. Moreover, because the disease is associated with soil nutrient imbalance [69], fertilizer management is very important. The abovementioned practices 
have been reported to minimize the disease incidence and severity. However, these practices are unable to eradicate the disease.

\subsection{Physical Treatment}

Infected planting materials are the primary source of pathogen inocula for the occurrence of red rot disease in sugarcane fields [8,28]. Many researchers had documented that sett borne red rot infection can be suppressed using heat therapy. Talukdar et al. [8] reported that moist hot air therapies $\left(54{ }^{\circ} \mathrm{C}\right.$ for $3 \mathrm{~h}$ and $\mathrm{RH} 95 \%$ ) can completely eradicate sett borne infection. In combination with heat and chemotherapy, mixing synthetic chemicals in a hot water controlled the red rot [2]. Talukdar et al. [70] stated that using moist hot air at $54{ }^{\circ} \mathrm{C}$ for $2 \mathrm{~h}$ was more effective in reducing the incidence of the red rot than using hot water at $50^{\circ} \mathrm{C}$ for $2 \mathrm{~h}$. Singh and Singh [57] reported that aerated stream at $52{ }^{\circ} \mathrm{C}$ or sett, soaking in cold running water for $48 \mathrm{~h}$ followed by 150-180 min of hot water treatment at $50^{\circ} \mathrm{C}$ can eliminate the pathogen from infected setts. Other practices which had been recommended for the red rot management include burning waste, preserving enough soil moisture and timely harvesting of contaminated or susceptible crops [71]. The advantages of the physical treatment are as follows: eco-friendly, easy to adopt, cheaper, and it kills setts borne pathogens. However, this intervention is time-consuming.

\subsection{Chemical Control}

In-vitro studies suggest that the chemical control method completely inhibits $C$. falcatum growth. For example, Benomyl ${ }^{\circledR} 50 \mathrm{WP}$, Folicar ${ }^{\circledR}$ and Radomil ${ }^{\circledR} 75 \mathrm{WP}(100 \%)$ at a level of $5-50 \mu \mathrm{gmL}^{-1}$ completely inhibited fungal growth [72]. Similarly, Bharadwaj and Sahu [73] reported complete inhibition of $C$. falcatum mycelia growth using Bavistin ${ }^{\circledR}$. However, their effectiveness in the field remains unproven. In the field, the role of sett treatment controls the primary source of red rot from setts [30], and the use of fungicides to combat red rot in the field is usually restricted to setts treatment. It is possible to reduce red rot incidence by treating the infected setts with carbendazim and benomyl for 30-60 min [74]. In some studies, dip treatment of sugarcane setts (handling debris borne infection $24 \mathrm{~h}$ before planting) with $0.25 \%$ suspension of thiophanate methyl and carbendazim metabolite effectively controlled red rot disease. Rahman et al. [75] reported that Topsin ${ }^{\circledR} \mathrm{M}$ treatment protected canes against red rot disease and the effectiveness increased cane yield. Using thiophanate methyl at $0.25 \%$ as sett treatments considerably suppressed red rot disease incidence [76]. The defense had been attributed to chemical antifungal effects on the pathogen. Fungicide thiophanate methyl also increased germination rate, tillers count, number of millable cane, weight of single cane, length of the cane, diameter of cane and yield of cane. In spite of these positive results, the literature is replete with many findings that the chemical treatment method has miniature effect on red rot disease because of rinds impermeability, presence of abundant nutrient in the area, the existence of fibrous nodes at the cutting ends, poor fungicide solubility and water in setts $[18,24]$. The benefit of the chemical treatment method is its efficacy because the effectiveness is better than other methods, but it is not eco-friendly.

\subsection{Use of Resistant Varieties against Red Rot}

The recurrent outbreak of red rot in epiphytotic condition had compelled breeders to develop red rot resistant varieties. The evolution of new races of the pathogen is a major factor for the breakdown of new varieties. Among the species of sugarcane, S. spontaneum is the most resistant species whereas S. officinarum is the least resistant species. Although the inherited genetics of the red rot resistant genes are not well established, there is significant progress in the development of resistant varieties against the red rot [23]. The red rot resistance is transferred in sugarcane species through interspecific, intraspecific or intergeneric crosses [77,78]. The focus of the breeding work in the Indian sub-continent is the development of red rot resistant varieties through interspecific crosses [52]. However, because the pathogen varies, after a disease-resistant variety is released for commercial cultivation, within 8 to 10 years, it becomes vulnerable to red rot disease because the pathogen evolves into a new and more 
virulent strain [4]. There are significant attempts to detect genes and markers which are related to the red rot resistance. Because of exceedingly heterozygous polyploid seed genome along with a constricted genetic base (based on the conventional and genetic mapping methods), it has been difficult to breed for red rot resistance in sugarcane. Although tags of differentially articulated sequences had been identified in response to the infection of $C$. falcatum they do not contribute to the discovery of the functional target gene(s) for resistance of the red rot because the study was conducted on a particular sugarcane genotype without exploring the history of segregation and epistatic interactions [79]. Singh et al. [80] developed recognized target genes for the red rot resistance following linkage imbalance-based interaction mapping. However, their role in imparting resistance to disease is yet to be confirmed thus, restricting their use as molecular markers for the detection of resistant genotypes and marker assisted collection for sugarcane. Recently, Nayyar et al. [81] discovered $\beta-1,3$ glucanasegene expressions from Trichoderma sp. The $\beta-1,3$ glucanasegene is responsible for the improvement of transgenic sugarcane that is resistant to the red rot. The integration of transgenic genes and their expression was confirmed in the first generation of $\mathrm{T}_{0}$ plants by quantitative reverse transcription PCR up to 4.4 times higher expression than with non-transgenic sugarcane. Two virulent pathotypes of C. falcatum (Cf08 and Cf09) which cause the red rot have been shown in bioassays of transgenic plants where some plants had resistance to Cf08 and mild resistance to Cf.09. Nayyar et al. [81] clarified that the resistant transgenic plants cells did not lose sucrose because of inhibition of fungal hyphae-to-hyphae or hyphae swelling. Hyphallysis occurs because of the action of $\beta-1,3$-glucanase on the $\beta$-1,3-glucosyl enzyme linkages of the fungal cell wall. This transgenic resistant and moderately tolerant sugarcane can also be used to develop resistant varieties against $C$. falcatum. For example, Isd 2/54, Isd 39, Isd 40, BSRI Akh 41, BSRI Akh 43, BSRI Akh 44,BSRI Akh 45 and BSRI Akh 46 and Co 8371, Co 85004, Co 86032,Co 94,008 and Co 94,270 are resistant varieties in Bangladesh and India [82-84].

\subsection{Biologic Control and Natural Products}

Eco-friendly and sustainable alternative approach to manage diseases is biological control. Different bio-control agents have been used either alone or in combination with other management methods to control C. falcatum in sugarcane. Among the biocontrol agents, plant growth-promoting rhizobacteria (PGPR) that are allied with root of sugarcane would be useful in sustaining plant growth through developing many plant growth-supporting metabolites [85]. Plant growth-promoting rhizobacteria at the rhizosphere of sugarcane plants improves the growth of sugarcane plants by colonizing their rooting zones. Plant growth-promoting rhizobacteria can also inhabit C. falcatum [86]. In recent times, different genera of bacterial such as Enterobacter, Pseudomonas, Burkholderia, Bacillus, Gluconaceto bacter and Ochrobactrum are known (in-vivo and in-vitro trials) to effectively inhibit C. falcatum in the sugarcane rhizosphere [86-88]. Patel et al. [16] conducted an in-vivo study against three strains of $C$. falcatum. The findings showed that Ochrobactrum intermedium (TRD 14) effectively regulated the pathogenicity of $C$. falcatum (cfNAV) and it also enhanced the growth of sugarcane plants by $8.2 \%$. Furthermore, the sugarcane plants with O. intermedium (TRD 14) increased stem diameter. In the case of Acinetobacter sp. (PK9) and Bacillus sp. (RSC 29) protection against C. falcatum strains, it was observed that the height and diameter of the stem of the sugarcane plants were not significantly improved. The sugarcane plants started drying after 45 days, but in the absence of red rot disease, the two strains increased height of the sugarcane stem. The most promising results were noticed using Escherichia sp. (VRE34) because it effectively suppressed the disease apart from improving the growth of sugarcane plants.

Trichoderma harzianum is another bio-agent which is being used to management red rot disease. The effectiveness of T. harzianum is related its direct parasitic effect on C. falcatum. Trichoderma harzianum application is reduces the economic losses in susceptible varieties. In addition, the use of T. harzianum increases cane yield because of the increased germination and shooting of biomass. Trichoderma bio-pesticide application is eco-friendly, economical, besides improving soil quality [41]. Trichoderma harzianum can directly control C. falcatum by producing systemic resistance in treated 
sugarcane plants [89]. The application of T. harzianum strain Th37 on stubbles at $20 \mathrm{~kg} / \mathrm{ha}$ increased nitrogen $(\mathrm{N})$, phosphorus $(\mathrm{P})$ and potassium $(\mathrm{K})$ availability by $27.65 \%$ and $44 \%$, respectively. The level of red rot defense increased to $78 \%$ when in combination with TMC/salicylic acid (SA) and $86 \%$ with metabolites/SA, where defense was $60 \%$ and $71 \%$, respectively. The commonly used bio-control agents against C. falcatum are summarized in Table 2.

Plant based extracts had also been reported to suppress $C$. falcatum. It has been reported that ginger, onion, and garlic extracts can inhibit mycelia development of $C$. falcatum. Applications of essential oils such as menthe oil, patchouli oil, peppermint oil and palm oil can also mitigate C. falcatum infection [73]. According to Imtiaj et al. [90], Datura metal and Curcuma domestica leaf extracts can inhibit both mycelia and conidial growth of the red rot pathogens. Similarly, tobacco and dhup smoke (incense) are thought to inhibit the red rot conidial germination. These findings were not obtained from field experiments. Thus, stages and detailed studies on their effectiveness in field evaluations are required. The use of biocontrol agents and natural products are eco-friendly, economically efficient for improving soil health and good for pathogens suppression for a long period. However, their field effectiveness is very low and currently, there is dearth of information on this aspect. To this end, emphasis on the formulation of durable bio products whose potencies can withstand different environmental challenges is essential.

Table 2. Potential biocontrol agents and their effects on red rot management in vitro or field trials.

\begin{tabular}{|c|c|c|c|c|}
\hline Classification & Bio-Agent & Effect & Recommendation & References \\
\hline \multirow{5}{*}{ Bacteria } & $\begin{array}{l}\text { Acinetobacter sp. PK9 } \\
\text { Bacillus safensis B1 } \\
\text { Bacillus megaterium PK2 } \\
\text { Cronobacter muytjensii VRE6 } \\
\text { Enterobacter sp. RSC32 } \\
\text { Enterobacter cloacae VRE7 Pseudomonas } \\
\text { plecoglossicida S2 Ochrobactrum } \\
\text { anthropi TRD11 } \\
\text { Ochrobactrum intermedium TRD14 } \\
\text { Stenotrophomonas acidaminiphila } \\
\text { Pseudomonas plecoglossicida S2 } \\
\text { Sphingobacterium } \\
\text { thalpophilumRSC24 }\end{array}$ & $\begin{array}{l}\text { Dual culture test indicated } 36 \% \\
\text { to } 60 \% \text { inhibition. }\end{array}$ & Field evaluation required & $\begin{array}{l}\text { Patel et al. [16] } \\
\text { Patel et al. [91] }\end{array}$ \\
\hline & Pseudomonas putida NH-50 & $\begin{array}{l}\text { Reduced disease severity by } \\
44-60 \% \text { in different field trials }\end{array}$ & $\begin{array}{l}\text { This strain possesses other } \\
\text { plant growth characteristics } \\
\text { and can be used as a } \\
\text { bio-pesticide for } \\
\text { sugarcane crop }\end{array}$ & Hassan et al. [88] \\
\hline & $\begin{array}{l}\text { Pseudomonas fluorescens } \mathrm{Md} 1 \\
\text { Abrus precatorius }\end{array}$ & $\begin{array}{l}\text { Significant level of disease } \\
\text { reduction and increase } \\
\text { yield in pot trials in glass } \\
\text { house experiment. }\end{array}$ & Field evaluation required & $\begin{array}{l}\text { Jayakumar et al. [92] } \\
\text { Senthil et al. [93] } \\
\text { Malathi et al. [94] }\end{array}$ \\
\hline & Bacillus subtilis NH-100, 160 and 217 & $\begin{array}{l}\text { Three strains of the genus } \\
\text { Bacillus reduced disease } \\
\text { incidence by } 45-49 \% \text { in } \\
\text { sugarcane plants challenged by } \\
\text { pathogen inoculation in } \\
\text { the stem and by } 48-56 \% \text { in } \\
\text { the plants inoculated in the soil } \\
\text { near the roots. }\end{array}$ & $\begin{array}{l}\text { The results of present study } \\
\text { suggest a potential use of } \\
\text { these strains in } \\
\text { the development of } \\
\text { commercial inoculants to be } \\
\text { applied for the control of red } \\
\text { rot disease }\end{array}$ & Hassan et al. [21] \\
\hline & Pseudomonas aurantiaca & $\begin{array}{l}\text { The endophytic bacterium } \\
\text { Pseudomonas aurantiaca PB-St2 } \\
\text { exhibits antifungal activity } \\
\text { and represents a biocontrol } \\
\text { agent to suppress red rot disease } \\
\text { of sugar cane in vitro. }\end{array}$ & Field trials required & Mehnaz et al. [35] \\
\hline Fungi & $\begin{array}{l}\text { Trichoderma harzianum Th } 37 \\
\text { T. viride } 6 \text { }\end{array}$ & $\begin{array}{l}\text { Red rot infection was } \\
\text { suppressed in } 20-28 \% \text { in } \\
\text { field trail. }\end{array}$ & $\begin{array}{l}\text { Sett and soil treatment with } \\
\text { T. harzianum and T. viride for } \\
\text { enhancing the yield }\end{array}$ & $\begin{array}{l}\text { Singh et al. [95] } \\
\text { Yadav et al. [89] }\end{array}$ \\
\hline
\end{tabular}

\section{Legislation (Quarantine)}

Plant quarantine laws enable government agencies to protect the entry of alien insects and pathogens into countries [96]. Uncontrolled setts cane movement is primarily responsible for spreading red rot disease. Therefore, it is important to limit cane transport from an infected area to disease free zones/areas [97]. Only research stations with valid phytosanitary certificates should import seeds [24]. Stringent implementation of these regulations is urgently needed. The lack of 
skilled personnel to certify the setts, extension services, and laboratory facilities in sugarcane growing countries may limit the implementation of the quarantine laws.

\section{Conclusions and Future Perspectives}

The red rot pathogen, C. falcatum, is a major threat to the sugar industry. It is believed that the inocula resides in crop debris, infected soils and infected setts, resting appressorial cell, conidia and mycelia. The genetic make-up of this fungus varies, making the management of red rot disease in sugarcane plantations difficult. Extensive disease testing using ELISA has been conducted and verified using PCR assay. Specific antibodies are required to avoid false positive and negative. The use of DNA-based nanosensors and DNA microarrays is also promising because these technologies are easier to adopt, they are more reliable and more cost-effective compared with the traditional PCR-based techniques. Non-molecular approaches such as screening for hyperspectral reflective data are being studied with some degree of success, but there is a long way from achieving accurate identification. Although biocontrol methods are promising, they require extensive field evaluation to develop bio-formulated products. It may be argued that both DNA fingerprinting and genome sequencing are ideally placed to include the evidence that is crucial for promoting phylogenetic and systematic research (until natural remedy to disease resistance becomes a reality). The currently the sugarcane planters are focused on the management of red rot disease through eliminating diseased materials that blur cultural traditions. Until C. falcatum resistant varieties are fully development, sanitation is the most practical red rot disease management method. In addition, an intense genome project on C. falcatum is urgently needed. Nonetheless, the occurrence of disease destruction has been considerably reduced as the field disease management has been well established. To sustain the sugarcane industry, intensive breeding work on coming out with red rot disease resistant sugarcane variety or developing biologic control technologies are essential.

Author Contributions: Conceptualization, M.I.H., K.A.; methodology, M.I.H., K.A. and Z.R.; investigation, K.A., Y.S.; N.S. and A.O.H.; and S.K.B.; data curation, M.I.H., Z.R.; writing original draft preparation, M.I.H., K.A., Y.S., S.K.B., N.S. and Z.R.; writing review and editing Y.S., K.A., N.S., S.K.B. and A.O.H. validation, K.A., Y.S., N.S. and A.O.H., supervision, K.A., Y.S., N.S. and A.O.H. All authors have read and agreed to the published version of the manuscript.

Funding: This work was funded by the National Agricultural Technology Program (NATP II) with Grant No. 6282513.

Acknowledgments: We thank the staffs from the Department of Plant Protection, Universiti Putra Malaysia, Bangladesh Sugarcrop Research Institute (BSRI) for their excellent technical assistance during the research and the National Agricultural Technology Program (NATP Phase II) Project of the Bangladesh Agricultural Research Council (BARC) for financial support.

Conflicts of Interest: The authors declare no conflict of interest.

\section{References}

1. Purseglove, J.W. Tropical Crops, Monocotyledons; Longman Group Ltd.: London, UK, 1979.

2. Thangamanil, P.R.; Thiruvengadam, R.; Thillaigovindan, K. Morphological characterization and reaction of partial purified toxin of sugarcane red rot pathogen Colletotrichum falcatum collected from Southern India. Int. J. Agric. Sci. 2013, 3, 60-78.

3. Gianotto, A.C.; Arruda, P.; Bespalhok, J.; Burnquist, W.W. Sugarcane (Saccharum X officinarum): A Reference Study for the Regulation of Genetically Modified Cultivars in Brazil. Trop. Plant Biol. 2011, 4, 62-89. [CrossRef] [PubMed]

4. Food and Agricultural Organization of United Nations. Economic and Social Department. The Statistical Division; FAO: Rome, Italy, 2018.

5. FAO; UNICEF. The State of Food Security and Nutrition in the World: Safe Guarding against Economic Slowdowns and Downturns; UNICEF: Paris, France, 2019.

6. OECD/FAO. OECD-FAO Agricultural Outlook, OECD Agriculture Statistics (Database); OECD: Paris, France, 2019; p. 162. [CrossRef] 
7. OECD. OECD-FAO Agricultural Outlook 2019-2028; OECD: Paris, France, 2019; pp. 156-162. [CrossRef]

8. Talukder, M.I.; Alam, M.S. Effect of moist hot air treatment (MHAT) on control of white leaf disease and growth of sugarcane. Pak. Sugar J. 2000, 15, 16-21.

9. Rott, P.; Bailey, R.A.; Comstock, J.C.; Croft, B.J.; Saumtally, A.S. A Guide to Sugarcane Disease; Cirad. Issct, Cirad Publication Services: Montepellier, France, 2000; p. 339.

10. Sharma, R.; Tamta, S. A Review on red rot: The "cancer" of sugarcane. J. Plant Pathol. Microbiol. 2015, 1, 1-8. [CrossRef]

11. Singh, O.; Waraitch, K.S. Effect of Wilt and Red Rot Induced Disease Stress on Quality Deterioration of Sugarcane. Sugarcane Pathol. Newsl. 1981, 27, 9-25.

12. Smith, B.J.; Black, L.L. Morphological, cultural and pathogenic variation among Colletotrichum species isolated from strawberry. Plant Dis. 1990, 74, 69-76. [CrossRef]

13. Bharti, Y.P.; Vishwakarma, S.K.; Kumar, A.; Singh, A.; Sharma, M.L.; Shukla, D.N. Physiological and Pathological Aspects of some new isolates of Colletotricum falcatum causing Red rot disease in Saccharum spp.complex. Acta Phytopathol. Entomol. Hung. 2012, 47, 35-50. [CrossRef]

14. Ghazanfar, M.U.; Kamran, S. Evaluation of Different Plant Extracts against Colletotrichum falcatum Causing Red Rot in Sugarcane under Lab Conditions. J. Environ. Agric. 2016, 1, 68-73.

15. Malathi, P.; Viswanathan, R.; Padmanaban, P.; Mohanraj, D.; Ramesh, A. Compatibility of biocontrol agents with fungicides against red rot disease of sugarcane. Sugar Tech 2002, 4, 131-136. [CrossRef]

16. Patel, P.; Shah, R.; Joshi, B.; Ramar, K.; Natarajan, A. Molecular identification and biocontrol activity of sugarcane rhizosphere bacteria against red rot pathogen Colletotrichum falcatum. Biotechnol. Rep. 2019, 21, e00317. [CrossRef]

17. Singh, D.; Tiwari, A.K.; Mall, S.; Shukla, B.; Ahmad, I.Z.; Rao, G.P. Morpholoical and molecular diversity among C. falcatum isolates causing red rot disease of sugarcane in Uttar Pradesh. In Proceedings of the 10th Pathology Workshop, Nanning, China, 7-11 May 2012; p. 9.

18. Sharma, G.; Singh, J.; Arya, A.; Sharma, S.R. Biology and Management of Sugarcane Red Rot: A Review. Plant Arch. 2017, 17, 775-784.

19. Viswanathan, R.; Padmanaban, P.; Selvakumar, R. Emergence of New Pathogenic Variants in Colletotrichum falcatum, Stalk Infecting Ascomycete in Sugarcane: Role of Host Varieties. Sugar Tech 2019, 22, 473-484. [CrossRef]

20. Cooper, R.M.; Flood, J.; Rees, R. Ganoderma boninense in oil palm plantations: Current thinking on epidemiology, resistance and pathology. Planter 2011, 87, 515-526.

21. Hassan, M.N.; Afghan, S.; Hafeez, F.Y. Suppression of red rot caused by Colletotrichum falcatum on sugarcane plants using plant growth-promotin grhizobacteria. BioControl 2010, 55, 531-542. [CrossRef]

22. Duttamajumder, S.K. Red Rot of Sugarcane; Indian Institute of Sugarcane Research: Lucknow, India, 2008; pp. 1-8.

23. Viswanathan, R.; Rao, G.P. Disease scenario and management of major sugarcane diseases in India. Sugar Tech 2011, 13, 336-353. [CrossRef]

24. Satyavir. Red Rot of Sugarcane Current Scenario. Indian Phytopathol. 2003, 56, 245-254.

25. Hossain, M.I.; Uddin, M.J.; Rahman, M.S. Evaluation of Some Sugarcane Genotypes against Red Rot (Colletotrichum falcatum Went.) Disease. Bangladesh J. Sugarcane 2015, 36, 113-118.

26. Nithya, K.; Bukhari, K.; Valluvaparidasan, V.; Paranidharan, V.; Velazhahan, R. Molecular detection of Colletotrichum falcatum causing red rot disease of sugarcane (Saccharum officinarum) using a scar marker. Ann. Appl. Biol. 2012, 160, 168-173. [CrossRef]

27. Malathi, P.; Viswanathan, R.; Sundar, R.A.; Padmanaban, P.; Prakasam, N.; Mohanraj, D.; Joth, R. Phylogenetic Analysis of Colletotrichum falcatum Isolates Causing Red Rot in Sugarcane. J. Sugarcane Res. 2011, 1, 69-74.

28. Tiwari, A.K.; Singh, A.; Singh, S.P.; Dagar, A.; Kumari, K.; Kumar, D.; Pandey, N.; Kumar, P. An Overview of Major Fungal Diseases of Sugarcane in India: Detection and Management Strategies. Molecular Markers in Mycology, Fungal Biology; Springer International Publishing: Cham, Switzerland, 2017; pp. 275-304.

29. Sutton, B.C.; Bailey, J.A.; Jeger, M.J. Colletotrichum: Biology, Pathology and Control; CAB International: Wallingford, UK, 1992; pp. 1-26.

30. Chakrabarty, P.; Chavhan, R.; Sable, S.; Narwade, A.; Monga, D.; Khadi, B. Development of sensitive molecular diagnostic tools for detection of economically important fungal pathogens of cotton. In Proceedings of the World Cotton Research Conference-4, Lubbock, TX, USA, 10-14 September 2007. 
31. Abbas, H.; Anwar, S.A.; Javed, N.; Iqbal, M.A.; Abid, N. Morphological variability among isolates of Colletotrichum falcatum Went; Infecting four cultivars of sugarcane. Pak. J. Phytopathol. 2010, 22, 101-104.

32. Kuckenberg, J.; Tartachnyk, I.; Noga, G. Temporal and spatial changes of chlorophyll fluorescence as a basis for early and precise detection of leaf rust and powdery mildew infections in wheat leaves. Precis. Agric. 2009, 10, 34-44. [CrossRef]

33. Phoulivong, S.; Cai, L.; Chen, H.; Mckenzie, E.H.; Abdelsalam, K.; Chukeatirote, E.; Hyde, K.D. Colletotrichum gloeosporioides is not a common pathogen on tropical fruits. Fungal Divers. 2010, 44, 33-43. [CrossRef]

34. Viswanathan, R.; Padmanaban, P.; Mohanraj, D.; Jothi, R. Indirect-ELISA technique for the detection of the red rot pathogen in sugarcane (Saccharum spp. hybrid) and resistance screening. Indian J. Agril. Sci. 2000, 70, 8-11.

35. Mehnaz, S.; Bauer, J.S.; Gross, H. Complete genome sequence of the sugar cane endophyte Pseudomonas aurantiaca PB-St2, a disease-suppressive bacterium with antifungal activity toward the plant pathogen Colletotrichum falcatum. Genome Announc. 2014, 2, e01108-13. [CrossRef] [PubMed]

36. Uddin, M.S.; Talukdar, M.I.; Rahman, M.S. Screening of red rot genotypes of sugarcane in Bangladesh. Bangladesh J. Sugarcane 2013, 33-34, 5-8.

37. Hiermath, L.; Naik, R.G. Rapid diagnosis of sugarcane red rot by Dot Immune Binding Assay (DIBA) technique. Indian J. Biotechnol. 2004, 3, 542-545.

38. Khalid, A.I.; Bukhari, K.; Nithya, V.; Valluvaparidasan, V.; Paranidharan, R.; Velazhahan, M. Detection of Colletotrichum falcatum causing red rot of sugarcane by enzyme linked immune sorbent assay. Arch. Phytopathol. Plant Prot. 2012, 45, 823-830.

39. Cai, L.; Hyde, K.; Taylor, P.; Weir, B.; Waller, J.; Abang, M.; Zhang, J.; Yang, Y.; Phoulivong, S.; Liu, Z. A polyphasic approach for studying Colletotrichum. Fungal Divers. 2009, 39, 183-204.

40. Hyde, K.D.; Chomnunti, P.; Crous, P.W.; Groenewald, J.Z.; Damm, U.; KoKo, T.W.; Shivas, R.G.; Summerell, B.A.; Tan, Y.P. A case for re-inventory of Australia's plant pathogen. Persoonia 2010, 25, 50-60. [CrossRef]

41. Shivas, R.G.; Tan, Y.P. A taxonomic re-assessment of Colletotrichum acutatum, introducing C. fioriniae comb. et stat. nov. and C. simmondsii sp. nov. Fungal Diver. 2009, 39, e122.

42. Weir, B.S.; Johnston, P.R.; Damm, U. The Colletotrichum gloeosporioides species complex. Stud. Mycol. 2012, 73, 115-180. [CrossRef] [PubMed]

43. Arade, P.C.; Singh, P.; Mahatma, M. Characterization of Colletotrichum falcatum Went. Causing red rot in sugarcane complex. Bioscan 2014, 9, 375-379.

44. Bayraktar, H.; Dolar, F.S. Genetic diversity of wilt and root rot pathogens of chickpea, as assessed by RAPD and ISSR. Turk. J. Agric. For. 2009, 33, 1-10.

45. Zhang, L.J.; Dai, S.L. Genetic variation within and among populations of Orychophragmu sviolaceus (Cruciferae) in China as detected by ISSR analysis. Genet. Resour. Crop Evol. 2010, 57, 55-64. [CrossRef]

46. Singh, K.; Singh, R.P. Red rot. In Sugarcane Diseases-Major Diseases; Red, R., Ricaud, C., Egan, B.T., Gillaspie, A.G., Hughes, C.G., Eds.; Elsevier: Amsterdam, The Netherlands, 1989; pp. 169-188.

47. Shahnazi, S.; Meon, S.; Ebrahimi, M. Characterisation, differentiation and biochemical diversity of Fusarium solani and Fusarium proliferatum based on cellular fatty acid profiles. Arch. Phytopathol. Plant Prot. 2013, 1-9. [CrossRef]

48. Viswanathan, R.; Prasanth, C.N.; Malathi, P.; Sundar, A.R. Draft genome sequence of Colletotrichum falcatum-A prelude on screening of red rot pathogen in sugarcane. J. Genom. 2016, 4, 1. [CrossRef]

49. Scindiya, M.; Malathi, P.; Kaverinathan, K.; Viswanathan, R.; Sundar, A.R. Molecular characterization of pathogenicity gene homologs in Colletotrichum falcatum causing red rot in sugarcane. Sugar Tech 2017, 19, 563-572. [CrossRef]

50. Nandakumar, M.; Malathi, P.; Sundar, A.R.; Viswanathan, R. Use of Green Fluorescent Protein Expressing Colletotrichum falcatum the Red Rot Pathogen for Precise Host-Pathogen Interaction Studies in Sugarcane. Sugar Tech 2020, 22, 112-121. [CrossRef]

51. Padhy, J.B.; Kumar, D.D.; Manish, L.; Lavanya, C. Leaf Disease Detection Using K-Means Clustering and Fuzzy Logic Classifier. IJESTA 2016, 2, 5.

52. Khan, A.; Yadav, M.; Singh, A.S. Image Processing Based Disease Detection for sugarcane. Int. J. Adv. Res. Ideas Innov. Technol. 2017, 3, 497-502. 
53. Berdugo, C.A.; Zito, R.; Paulus, S.; Mahlein, A.K. Fusion of sensor data for the detection and differentiation of plant diseases in cucumber. Plant Pathol. 2014, 63, 1344-1356. [CrossRef]

54. Bürling, K.; Hunsche, M.; Noga, G. Use of blue-green and chlorophyll fluorescence measurements for differentiation between nitrogen deficiency and pathogen infection in winter wheat. J. Plant Physiol. 2011, 168, 1641-1648. [CrossRef] [PubMed]

55. Scholes, J.D.; Rolfe, S.A. Chlorophyll fluorescence imaging as tool for understanding the impact of fungal diseases on plant performance: A phenomics perspective. Funct. Plant Biol. 2009, 36, 880-892. [CrossRef] [PubMed]

56. Oerke, E.; Steiner, U.; Dehne, H.W.; Lindenthal, M. Thermal imaging of cucumber leaves affected by downy mildew and environmental conditions. J. Exp. Bot. 2006, 57, 2121-2132. [CrossRef]

57. Stoll, M.; Schultz, H.R.; Baecker, G.; Berkelmann-Loehnertz, B. Early pathogen detection under different water status and the assessment of spray application in vineyards through the use of thermal imagery. Precis. Agric. 2008, 9, 407-417. [CrossRef]

58. Oerke, E.C.; Fröhling, P.; Steiner, U. Thermographic assessment of scab disease on apple leaves. Precis. Agric. 2011, 12, 699-715. [CrossRef]

59. Jafari, M.; Minaei, S.; Safaie, N. Detection of pre-symptomatic rose powdery-mildew and gray-mold diseases based on thermal vision. Infrared Phys. Tech. 2017, 85, 170-183. [CrossRef]

60. Kumar, N.; Jhang, T.; Satyavir, N.; Sharma, T.R. Molecular and Pathological Characterization of Colletotrichum falcatum Infecting Subtropical Indian Sugarcane. J. Phytopathol. 2010, 159, 260-267. [CrossRef]

61. Hillnhütter, C.; Mahlein, A.K.; Sikora, R.A.; Oerke, E.C. Remote sensing to detect plant stress induced by Heterodera schachtii and Rhizoctonia solani in sugar beet fields. Field Crops Res. 2011, 122, 70-77. [CrossRef]

62. Apan, A.; Held, A.; Phinn, S.; Markley, J. Detecting sugarcane 'orange rust' disease using EO-1 Hyperion hyperspectral imagery. Int. J. Remote Sens. 2004, 25, 489-498. [CrossRef]

63. Maryam, K.; Khairunniza, B.; Biswajeet, P. Geospatial technologies for detection and monitoring of Ganoderma basal stem rot infection in oil palm plantations: A review on sensors and techniques. Geocarto Int. 2018, 33, 260-276.

64. Apan, A.; Held, A. In-House Workshop on Hyperion Data Processing: Echoing the Sugarcane Project Experience (Black Mountain Laboratories, Canberra: CSIRO Land and Water); Black Mountain Laboratories: Canberra, Australia, 2002.

65. Eun, A.J.C.; Wong, S.M. Molecular beacons: A new approach to plant virus detection. Phytopathology 2000, 90, 269-275. [CrossRef] [PubMed]

66. Ivnitski, D.; Abdel-Hamid, I.; Atanasov, P.; Wilkins, E.; Stricker, S. Application of electrochemical biosensors for detection of food pathogenic bacteria. Electroanalysis 2000, 12, 317-325. [CrossRef]

67. Sandeep, J.; Chahal, S.S. Molecular and morpho-pathological variation in Bipolarisoryzae (Breda de Haan) shoem causing brown spot of rice in North India. Crop Improv. 2011, 38, 103-108.

68. Agnihotri, V.P. Current sugarcane disease scenario and management strategies. Indian Phytopathol. 1996, 49, 109-126.

69. Gupta, R.N.; Sah, S.B.; Kumar, S.; Kumar, A.; Kishore, C.; Chand, G. Impact of red rot disease on nutrient status of sugarcane. Int. J. Curr. Microbiol. App. Sci. 2018, 17, 3533-3538.

70. Talukder, M.I.; Kamal, M.M.; Iqbal, M.; Rahman, S. Bangladesh Akher Rog Balai Somuho O Tar Pratikar; Bangladesh Sugarcane Research Institute: Ishurdi, Pabna, Bangladesh, 2010; pp. 5-10.

71. Anower, S.; Khan, H.W.A.; Chatta, A.A. Integrated management of sugarcane diseases and insects in Pakistan. In Proceedings of the International Symposia on Sustainable Sugarcane and Sugar Production Technologies, Nanning, China, 29 November-2 December 2004; pp. 468-471.

72. Subhani, M.N.; Chaudhry, M.A.; Khaliq, A.; Muhammad, F. Efficacy of Various Fungicides against Sugarcane Red Rot (Colletotrichum falcatum). Int. J. Agric. Biol. 2008, 10, 725-727.

73. Bharadwaj, N.; Sahu, R.K. Evaluation of some fungicides, botanicals and essential oils against the fungus Colletotrichum falcatum causing red rot of sugarcane. Bioscan 2014, 9, 175-178.

74. Malathi, P.; Viswanathan, R. Role of microbial chitinase in the biocontrol of sugarcane red rot caused by Colletotrichum falcatum Went. Electron. J. Plant Breed. 2013, 6, 17-23.

75. Rahman, M.S.; Talukder, M.I.; Iqbal, M.; Begum, F.; Khatun, S. Reaction of some sugarcane genotypes against red rot (Colletotrichum falcatum Went.) disease. Indian Sugar 2009, 59, 35-40. 
76. Kumar, A. Effect of Thiophanate Methyl on Red Rot Disease (Colletotrichum falcatum) and Yield Attributes of Sugarcane. J. Pharmacogn. Phytochem. 2017, 163-167. Available online: http:www.phytojournal.com (accessed on 1 July 2009).

77. Alexander, K.C.; Rao, M.M. Comparative evaluation of genotypes in the centres in India for resistance to red rot and smut. In Proceedings of the Diamond Jubilee Symposium of Sugarcane Breeding Institute, Sugarcane Breeding Station, Coimbatore, India, 25 September 1972; pp. 12-24.

78. Babu, C.N.; Koodalingram, U.S.; Nataranjan, R.M.; Santhi, P.; Govindaraj, P. Genetic inhencement of Sugarcane (Scharachum sp. Hybrids) for resistance to red rot disease and economic traits. J. Agric. Sci. 2009, 4, 97-107.

79. Prathima, P.; Suparna, T.; Anishma, S.; Punnya, R.; Ramalashmi, K. Cloning and characterization of a differentially regulated invertase inhibitor gene during sucrose accumulation in sugarcane. J. Sugarcane Res. 2014, 4, 21-28.

80. Singh, R.K.; Kumar, P.; Tiwari, N.N.; Singh, S.P.; Tiwari, A.K.; Kumar, A. Role of endochitinase gene and efficacy of Trichoderma against Colletotrichum falcatum Went. Causing red rot disease in sugarcane. Sugar Tech 2014, 16, 180-188. [CrossRef]

81. Nayyar, S.; Sharma, B.K.; Kaur, A.; Kalia, A.; Sanghera, G.S.; Thind, K.S.; Sandhu, J.S. Red rot resistant transgenic sugarcane developed through expression of $\beta-1$, 3-glucanase gene. PLoS ONE 2017, 12, 1-16. [CrossRef]

82. Available online: http://agropedia.iitk.ac.in/content/varieties-sugarcane (accessed on 1 July 2009).

83. Rahman, M.S.; Khatun, K.; Rahman, K. Sugarcane and sugar industry in Bangladesh: An Overview. Sugar Tech 2016, 18, 627-635. [CrossRef]

84. Uddin, M.J.; Rahman, M.S.; Hossain, M.I. Pathological Study of Sugarcane Variety BSRI Akh 45 Resistant to Red Rot Disease. Eco-Friendly Agric. J. 2016, 9, 60-62.

85. Bhardwaj, G.; Shah, R.; Joshi, B.; Patel, P. Klebsiellapn eumoniae VRE36 as a PGPR isolated from Saccharum officinarum cultivar Co99004. J. Appl. Biol. Biotechnol. 2017, 5, 47-52. [CrossRef]

86. Katiyar, D.; Hemantaranjan, A.; Singh, B. Application of Plant Growth Promoting Rhizobacteria in Promising Agriculture: An Appraisal. J. Plant Physiol. Pathol. 2017, 5, 2. [CrossRef]

87. Katiyar, A.; Hemantaranjan, B.; Singh, A.K.; Malakar, D. Isolation and characterization of plant growth promoting rhizobacteria Enterobacter hormaechei and their suppression efficacy against Colletotrichum falcatum in combination with Chitosan. Int. J. Plant Soil Sci. 2017, 14, 1-12. [CrossRef]

88. Hassan, M.N.; Afghan, S.; Hafeez, F.Y. Biological Suppression of Sugarcane Red Rot by Bacillus spp. Under Field Conditions. J. Plant Pathol. 2012, 94, 325-329.

89. Yadav, R.L.; Singh, S.N.; Srivastava, R.J.; Lal, S.K.; Awasthi Joshi, B.B. Use of Trichorderma harzium for the control of red rot disease of sugarcane. Sugarcane Int. 2008, 26, 28-33.

90. Imtiaj, A.; Alam, S.M.; Islam, A.K.M.R.; Alam, S.; Lee, T.S. In vitro studies on Colletotrichum falcatum the causal of red rot disease of sugarcane. Eurasian J. Agric. Environ. Sci. 2007, 2, 511-517.

91. Patel, P.; Shah, R.R.; Modi, K.K. Isolation and Characterization of Plant Growth Promoting Potential of Acinetobacter sp.RSC7 Isolated from Saccharum officinarum cultivar Co 671. J. Exp. Biol. Agric. Sci. 2017, 5, 483-891. [CrossRef]

92. Jaykumar, V.; Bhaskaran, R.; Tsushima, S. Potential of plant extract in combination with bacterial antagonist treatment as biocontrol agent of red rot of sugarcane. Can. J. Microbiol. 2007, 53, 196-206. [CrossRef] [PubMed]

93. Senthil, N.; Raguchander, T.; Viswanathan, R.; Samiyappan, R. Talc formulated fluorescent Pseudomonads for sugarcane red rot suppression and enhanced yield under field conditions. Sugar Tech 2003, 5, 37-43. [CrossRef]

94. Malathi, P.; Padmanaban, P.; Viswanathan, R.; Mohanraj, D. Interaction between Colletotrichum falcatum pathotypes and biocontrol agents. Arch. Phytopathol. Plant Prot. 2008, 41, 311-317. [CrossRef]

95. Singh, V.; Srivastava, R.L.; Awasthi, S.K.; Joshi, B.B. Biological control of red rot disease of sugarcane through Trichoderma harzianum and Trichoderma viride. Ind. Phytopathol. 2008, 61, 486-491. 
96. Anonymous. Krish Diary, Agricultural Information Service; Department of Agricultural Extension (DAE): Khamarbari, Bangladesh, 2016; pp. 54-55.

97. Anonymous. Proceedings and Recommendations. All India Coordinated Project on Sugarcane; Indian Institute of Sugarcane Research: Lucknow, India, 1998; pp. 10-15.

(C) 2020 by the authors. Licensee MDPI, Basel, Switzerland. This article is an open access article distributed under the terms and conditions of the Creative Commons Attribution (CC BY) license (http://creativecommons.org/licenses/by/4.0/). 